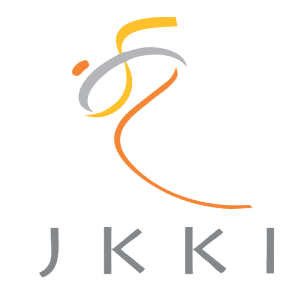

SCIEMTIR EST BASIC VITAE

\section{Jurnal Kedokteran dan Kesehatan Indonesia}

Indonesian Journal of Medicine and Health

Journal homepage: www.journal.uii.ac.id/index.php/jkki

\title{
Comparison of communication skill of medical students between activist and non activist
}

\author{
Mahdea Kasyiva ${ }^{* 1}$ Warenda Wisnu Aulia Rakhman ${ }^{1}$ Syaefudin Ali Akhmad ${ }^{1}$ \\ ${ }^{1}$ Faculty of Medicine Islamic University of Indonesia
}

Original Article

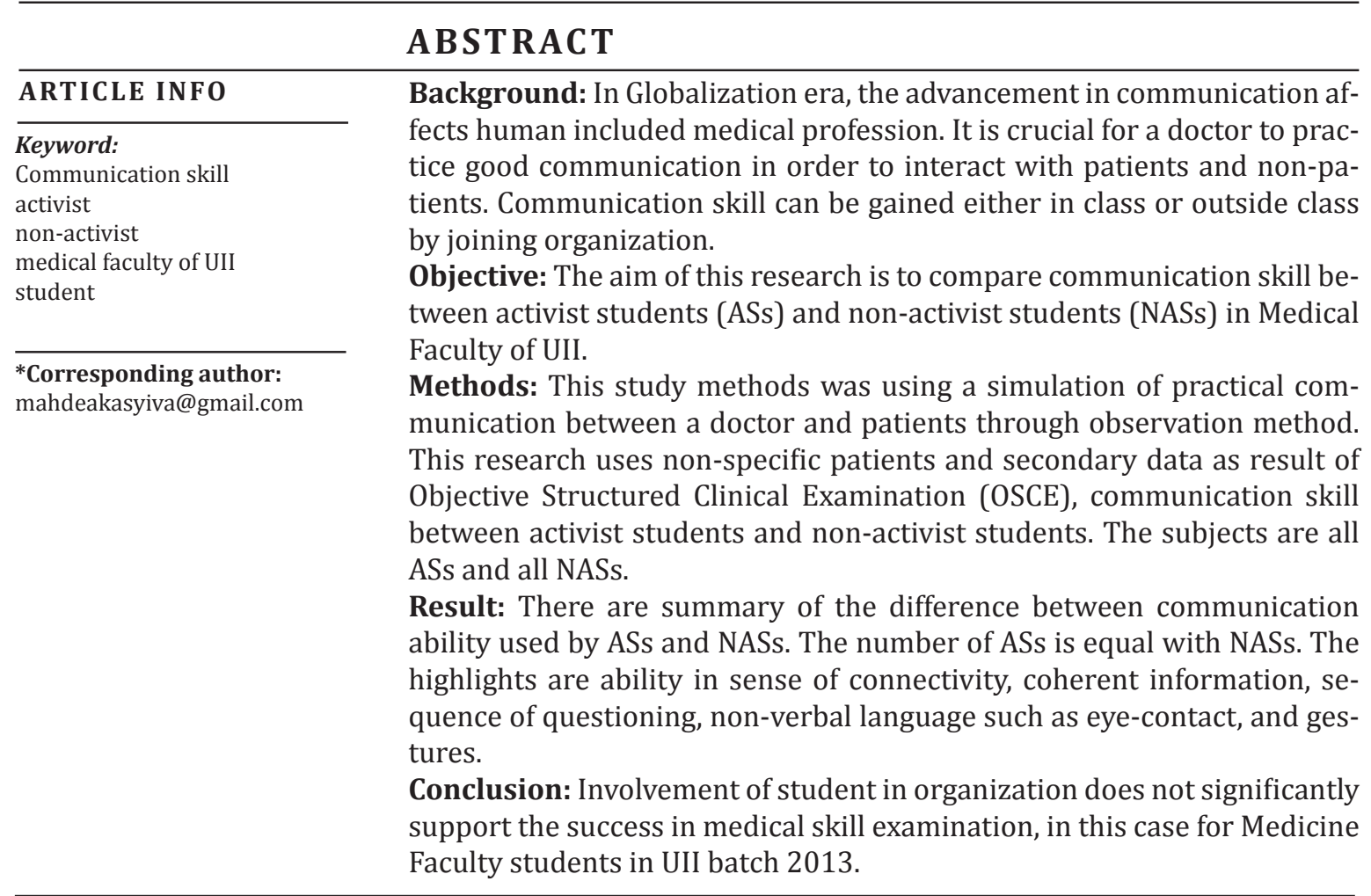

Latar belakang: Kemajuan omunikasi dalam era globalisas berdampak pada manusia termasuk profesi medis di dalamnya. Sangat penting untuk seorang dokter dapat berkomunikasi dengan baik dalam tujuannya untuk berinteraksi dengan pasien dan non pasien. Kemampuan komunikasi dapat di tingkatkan baik didalam maupun di luar kelas dengan mengikuti organisasi.

Tujuan : Riset ini bertujuan untuk membandingkan kemampuan komunikasi antara mahasiswa yang mengikuti organisai (Ass) dan yang tidak mengikuti (NASs) di Fakultas Kedokteran UII.

Metode: Riset ini menggunakan metode simulasi praktek komunikasi antara dokter dan pasien melalui metode observasi. Riset ini menggunakan pasien non spesifik dan data sekunder sebagai hasil dari Objective Structured Clinical Examination (OSCE), mahasiswa yang mengikuti organisai (Ass) dan yang tidak mengikuti (NASs). Subyek riset adalah semua Ass dan NASs.

Hasil: Terdapat perbedaan kemampuan komunikasi yang digunakan antara Ass dan NASs. Angka dari 
Ass setara dengan NASs. Hal yang penting yang diperoleh dari penilitian ini adalah sambung rasa, mendapatkan informasi yang koheren, pertanyaan yang berurutan, bahasa non-verbal seperti kontak mata dan bahasa tubuh.

Kesimpulan: Keterlibatan dari mahasiswa Fakultas Kedokteran UII angkatan 2013 di sebuah organisasi tidak mendukung secara signifikan terhadap kesuksesan dalam keterampilan medik.

\section{INTRODUCTION}

Communication and technology become growing rapidly entering human life in globalization era. The advancement of communication and information gives an important effect in the multi aspect of life, especially in medical field. The effective and efficient communication is a way for getting best practice in order to minimize misunderstanding between a physician and a patient, and also between a physician and a stakeholder. ${ }^{1}$

Misunderstanding between a physician and a patient could drag a physician further into malpractice. Therefore, Faculty of Medicine, University of Islam Indonesia wants to assist a physician in understanding and using proper communication skills. Because communication skills are important for physician-patient relationship, Medical Faculty of UII has included communication subject in the first-year curriculum in order for better understanding communication skills as early as possible. It discusses the meaning of communication between a doctor and a patient; a proper communication technique and benefit of good communication. Every student practice in a small group almost in every meeting, for example, in a tutorial and medical skill based on basedcompetence of a doctor to strengthen effective communication. $^{2}$

Communication practice occurs not only in class (academically) but also happens outside class, through students organizations in campus. It is not surprising that deans encourage all students to be active in organizations, as it also a commitment of Medical Faculty of UII. By involving oneself in an organization, a student can practice and improve his/her communication skill, which is also helpful in learning process.

\section{METHOD}

This research uses data from Medicine Faculty of UII on July 2015. Samples are second year students in 2013 in Medical Faculty of UII. Research adopts cross sectional methodology that analysis 110 people as population. There are two methods used to gather data; first, questionnaire about organization and second is students' score of OSCE done in last semester in Medical Faculty of UII.

Inclusive criteria, respondents are active students of Medical Faculty of UII, batch 2013 who filled out the questionnaire and joined OSCE examination (communication skill). Whilst, exclusive criteria, respondent are students who are not in batch 2013, and batch 2013 students who neither did fill out the questionnaire nor joined OSCE examination (communication skill).

\section{RESULT}

There were 10 from 110 respondents who did not meet inclusive criteria so that only 100 left and used as data. Data from questionnaire and examination score were grouped into three and calculated with percentage as follow.

Table 1. Respondents group and Respondents' failed

\begin{tabular}{cccccc}
\hline \multirow{2}{*}{ Group } & \multicolumn{2}{c}{ Respondent } & \multicolumn{2}{c}{ Failed } \\
\cline { 2 - 6 } & & Total & $\%$ & Total & $\%$ \\
\hline \multirow{2}{*}{ Activist } & AD & 48 & 48 & 11 & 23 \\
\cline { 2 - 6 } & AND & 37 & 37 & 11 & 30 \\
\hline \multicolumn{2}{c}{ Non-Activist } & 15 & 15 & 1 & 7 \\
\hline Notes AD & : Delegation-Activist & \\
& AND & : Non-Delegation Activist
\end{tabular}

The chart below shows total percentage of failed respondents.

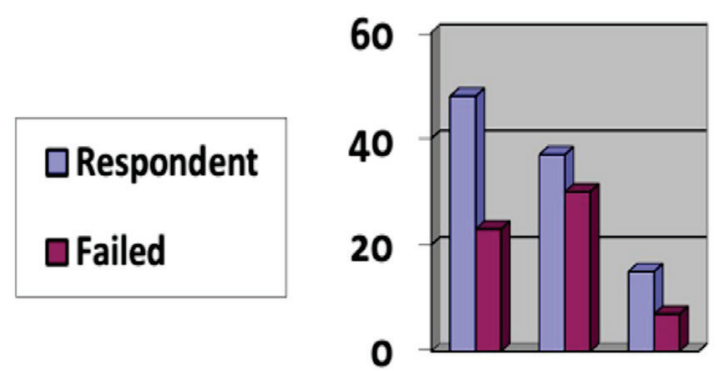

Figure 1 Chart of total respondents who are failed 


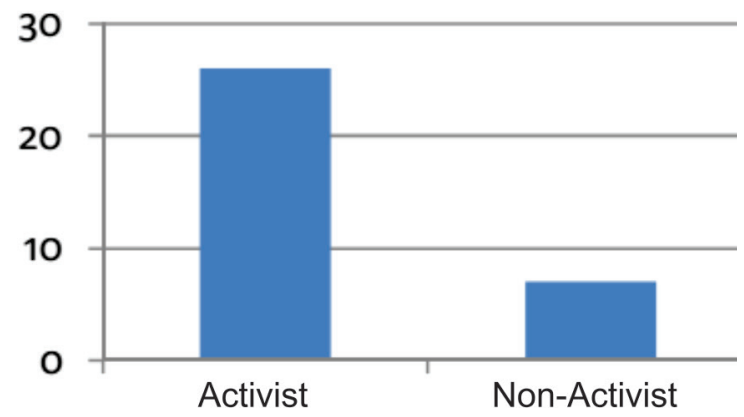

Figure 2 Chart of non-activist student and activist students who are failed

The chart shows comparison between number of failed students both who are activist and non-activist. The activist students who are failed is more numerous than non-activist.

\section{DISCUSSION}

Communication is an activity of delivering and receiving ideas, information, feeling and even emotion of a person, with the goal of communication that the message is received well by the recipient. ${ }^{3}$ In medical field, success communication is emphasized for doctor spends most time communicate directly with patient.

Effective communication between doctor and patient is crucial to support therapy process, medical treatment. ${ }^{4}$ Through effective communication, a doctor is able to understand well patient's condition and his/her family's as well, which is helpful for patient's healing process. Besides, effective communication helps a doctor to monitor patient's condition with the patient him/herself. ${ }^{3}$

Indonesian Medical Council designed seven core competences that are highly recommended for doctor to study. Those are: 1)Ethics, moral, medicolegal, professionalism and patient safety; 2)Self-awareness and self development; 3)Effective communication; 4)Information handling;5)Basic medical knowledge; 6)Clinical skills; 7)Health problem management. ${ }^{2}$

Effective communication can be created with continues practice, exercise person's soft skill. It can be practiced not only in formal education activity, but also in organization. ${ }^{5}$ By being active in organization, a student can assess more time to practice communication skill. ${ }^{6}$

Medical Faculty of UII has implemented communication study in curriculum, which skill in patient management; giving anamnesis, therapy and so on will be assessed in last semester through medical skill examination or known as OSCE. Through the examination, we can see number of successful students in communicating with patient and handling it. ${ }^{7}$

The research on Medical Student of UII batch 2013, OSCE examination being active in organization shows result about significant differences between ASs and NASs. Percentage of NASs who failed the examination is lower than ASs. This means organization activity does notstrongly effect result of communication skill examination of medical students.

\section{CONCLUSSION}

Communication skills have important role for students in Medicine Faculty. However, involvement of student in organization does not significantly support the success in medical skill examination, in this case for Medicine Faculty students in UII batch 2013, thus it is suggested to do further research.

\section{REFERENCES}

1. Rusmana A. Komunikasi Efektif Dokter Gigi Vs Pasien. Bandung: Universitas Padjajaran; 2007.

2. Indonesia KK. Standar Kompetensi Dokter Indonesia. 2012; 3-31 p.

3. Indonesia KK. Manual Komunikasi Efektif Dokter-Pasien. Jakarta: Lembaga Peraturan Bisnis Indonesia; 2006.

4. Setianti Y. Komunikasi Terapeutik antara Perawat dan Pasien. Jatinangor: Universitas Padjajaran; 2007.

5. Ramadona. Psikologi Komunikasi. Bandung: Remaja Rosdakarya; 2009.

6. Surya D. Manajemen Kinerja Falsafah Teori dan Penerapannya. Yogyakarta: Pustaka Pelajar; 2010.

7. Yedidia MJ, Gillespie CC, Kachur E, Schwartz MD, Ockene J, Chepaitis AE, et al. Effect of Communications Training on Medical Student Performance. JAMA 2003; 290(9):1157-65. 